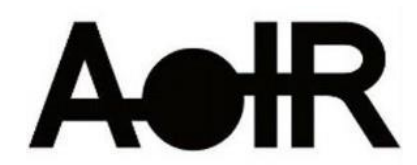

Selected Papers of \#AoIR2021:

The 22nd Annual Conference of the

Association of Internet Researchers

Virtual Event / 13-16 Oct 2021

\title{
CROWDFUNDING IN REMOTE CONFLICTS: BOUNDING THE HYPERCONNECTED BATTLEFIELD
}

Olga Boichak

The University of Sydney

Gregory Asmolov

King's College London

\section{Introduction}

The notion of 'participative war' (Merrin, 2019) highlights new forms of remote participation in armed conflicts afforded by social technology platforms. Conflating digital and physical battlefronts and eliding the distinction between military and civilians, platforms reconstitute the social conditions shaping people's relationship to wars (Hoskins \& O'Loughlin, 2010). Attending to these networked transformations, literature on participation in wars has been heavily focused on their information aspects, including witnessing, memory, influence operations and computational propaganda. To date, research on sociomaterial practices surrounding hyperconnected battlefields (e.g., Asmolov, 2021; Chouliaraki, 2015) remains scarce: there is a gap in understanding how the architectures of participation afforded by Web 2.0 shape wartime social processes 'on the ground', including military logistics and the delivery of humanitarian aid to affected populations (Boichak, 2019).

Recent political conflicts in Eastern Europe, including the armed conflicts in Ukraine and Nagorno-Karabakh have demonstrated that the scope of digitally mediated participation in war-related activities is much broader and goes far beyond the information domain (Boichak, 2017). An additional case to consider is the Belarusian protests: despite being a political conflict, the streets of major Belarusian cities can be also considered an urban battlefield that attracted global attention in the real time and offered opportunities for remote participation. A rapidly emerging sociomaterial practice in this context is the use of crowdfunding platforms to provide aid to the conflict-affected military and civilian populations. Echoing the conference theme, we investigate the role crowdfunding platforms play in fostering novel forms of interdependence among users as geopolitical actors in remote conflicts. Situating the inquiry in the ongoing military and political conflicts in Eastern Europe, we undertake the 'logistic turn' to explore the mediation of distant

Suggested Citation (APA): Boichak, Olga and Gregory Asmolov. (2021, October). Crowdfunding in Remote Conflicts: Bounding the Hyperconnected Battlefield. Paper presented at AolR 2021: The 22nd Annual Conference of the Association of Internet Researchers. Virtual Event: AolR. Retrieved from http://spir.aoir.org 
suffering through conflict-related crowdfunding. We ask: how do crowdfunding platforms constitute relationships between spectators and the hyperconnected battlefield, and what is the role of remote human suffering therein?

\section{Background}

Remote humanitarian participation in response to disasters and conflicts has a rich history that dates back at least a hundred years. Mediated by symbolic and material artefacts boundary objects (Star and Grisemer, 1989) - various forms of crowdfunding helped foster relationships between the intersecting social worlds of conflict and those of its remote spectators. Postage stamps (Figure 1) were a popular boundary object of the epistolary communicative tradition, drawing public attention to the suffering of veterans, their families, those with war related disabilities, and children orphaned by wars.

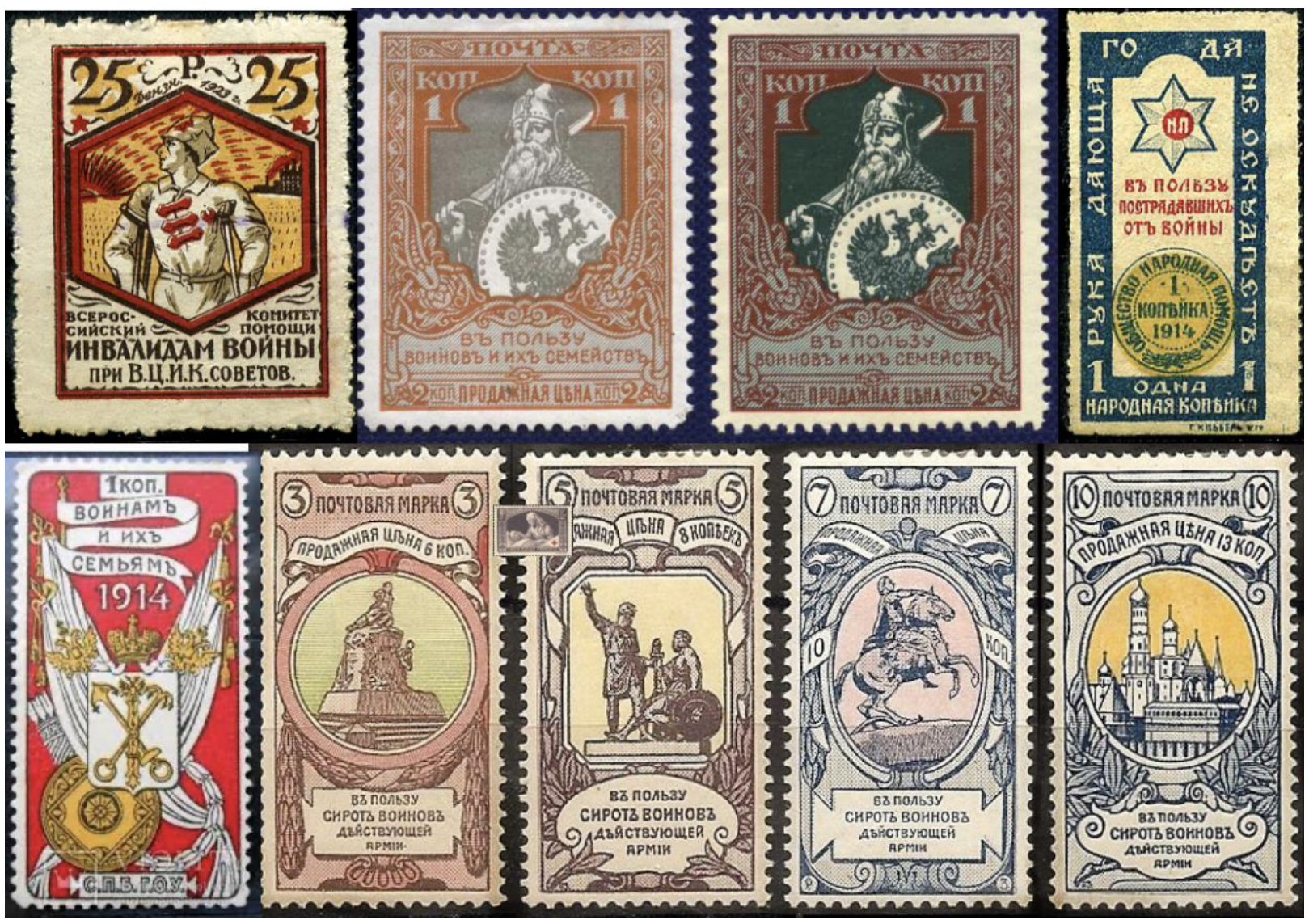

Figure 1. WWI-era stamps from the Russian Empire. Courtesy of the author(s).

In the contemporary time, the duration and extent of remote involvement among the public is known to be driven by three groups of factors: personal ties, remote suffering, and identity and expressions of patriotism (Boulianne et al., 2018). These heterogeneous geographies, histories, and cultures of care turn crowdfunding platforms into a complex site of empirical analysis (Figure 2). Crowdfunding platforms mediate the relationship between information sharing and capacity for action and afford an array of opportunities for responding to crisis events. Serving as conduits for involvement in conflicts, crowdfunding platforms are capable of accelerating response timelines as information, including photos and eyewitness accounts, as well as contact information and resources, 
can be posted and shared synchronously while those events are unfolding. In crowdfunding platform-mediated spaces, news and requests for help might come from the victims and survivors of crisis directly, avoiding media organisations and other institutional intermediaries (Boulianne et al., 2018). An ongoing discussion in the literature is whether these new forms of mediation constitute users as remote spectators, or allows for new forms of participation, and the effect it might have on the types and sets of boundary objects involved in the process.

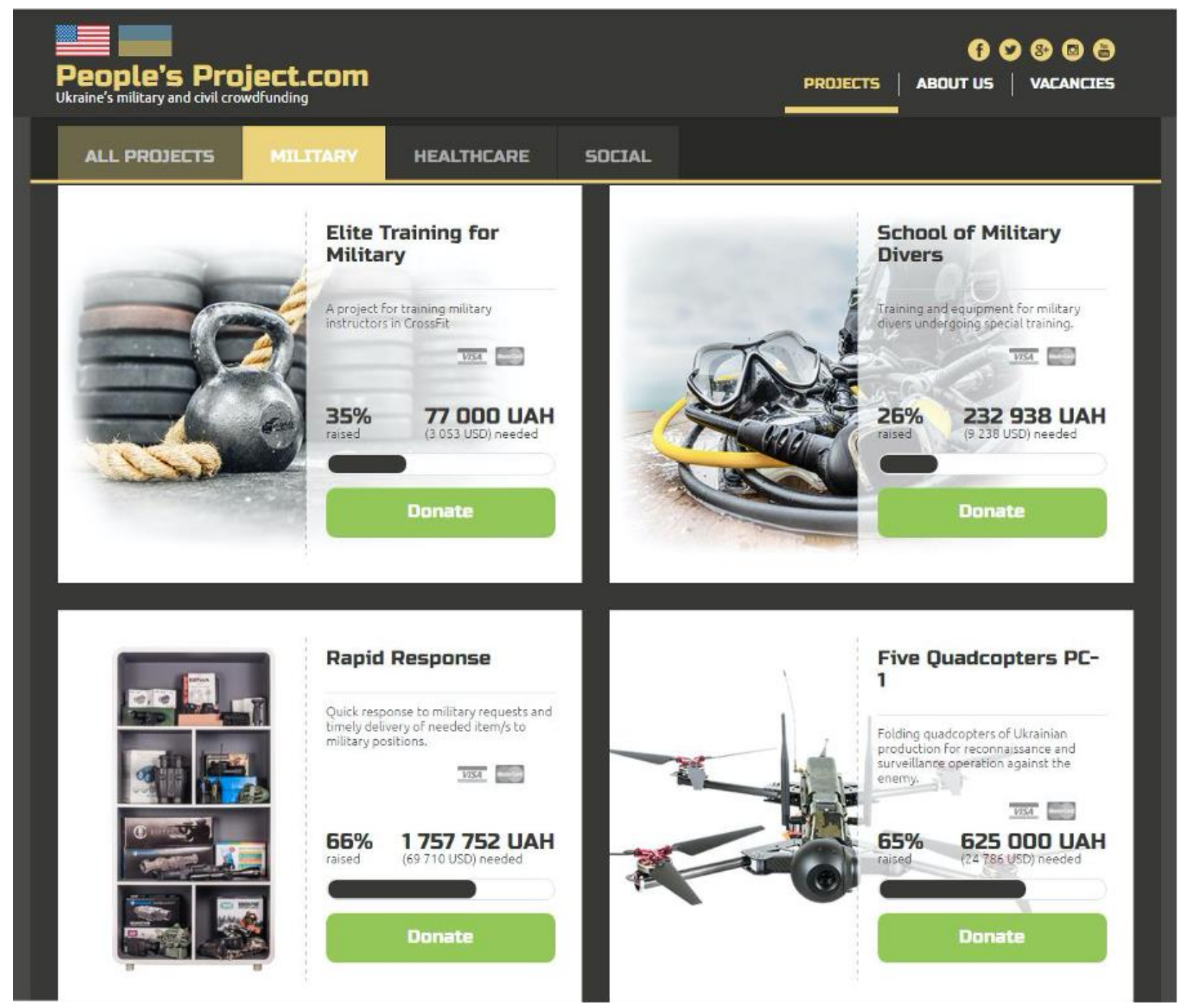

Figure 2. People's Project [Screenshot]. Retrieved from http://www.peoplesproject.com/

\section{Data and Method}

Situating our inquiry in the ongoing conflicts in the Eastern European region, we chose six prominent crowdfunding platforms for inclusion in our comparative case study: People's Project, Come Back Alive (Ukraine); Anna Astvatsaturian Foundation, Hayastan All-Armenian Fund (Armenia); \#BYSOL, BelarusTogether (Belarus, Figure 3). Drawing on data craft, a theory/method package for critical internet studies (Acker \& Donovan, 2019), we investigate two sets of boundary objects that mediate the connection between zones of conflict and their remote participants. The first set has to do with the crowdfunded artefacts, both tangible and intangible (from medical supplies, tactical equipment, and 
prosthetics to refugee resettlement, environmental and educational initiatives). The second set of boundary objects are the mediated representations of human suffering, which get curated, ordered, and circulated by algorithmic media. Accounting for the structural and functional diversity of conflict-related crowdfunding platforms, we then position these objects on a matrix based on their discursive and material significance: the narratives of suffering and the artefacts that are being funded to alleviate it.

\section{BYSOL fundraising}

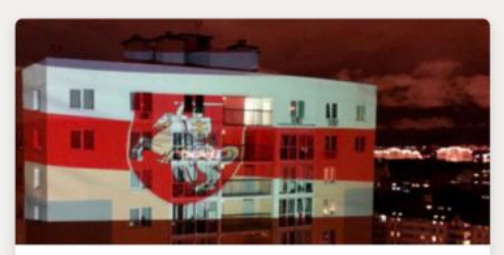

Support courtyard initiatives

Unique Belarusian courtyards are a phenomenon of protests. Small communities unite people across the country in their fight against dictatorship. They help Belarusians to openly express their protest, and we must help them to continue their struggle.

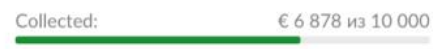

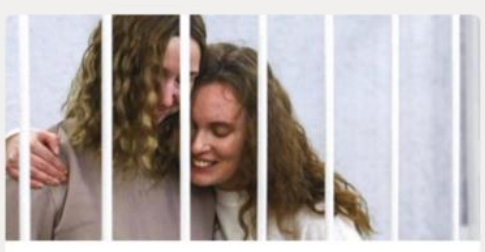

Support the families of political prisoners

In Belarus, 322 people ended up in prisons because they did not want to turn the blind eye to the terrible actions of the authorities. Support is needed not only for them but also for their families.

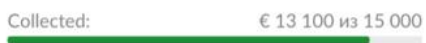

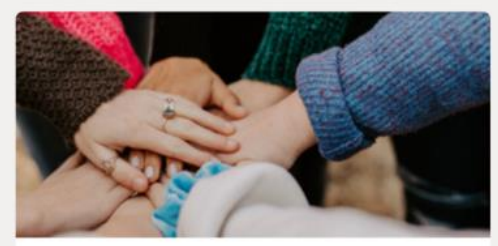

Team fundraising

Until August 2020, we, like all Belarusians, were engaged in our own projects, but we couldn't stay away when the country was gripped by a wave of violence and lawlessness. Now we help those who suffered at the hands of the regime.

\section{Figure 3. BYSOL Crowdfunding [Screenshot], Retrieved from: https://bysol.org/en/}

\section{Findings \& Discussion}

Through its participatory architectures, crowdfunding problematises the traditional tropes of international humanitarianism, whereby those who suffer are not merely the recipients of relief, conveying the promise of authentic, diffused, and multifaceted selfrepresentations by the communities in crisis. In fact, our analysis shows that crowdfunded goods and services - the first set of boundary objects that link to the conflict zone - elide the distinction between military and civilian logistics even further due to being a complement, or at times a substitute, of those traditionally provided by the state. In this context, one may argue that crowdfunding is just a new term used to describe conflict related fundraising mostly related to different forms of humanitarian assistance.

At the same time, conflict-related crowdfunding could be considered a new form of identity proclamation with regard to the users' positionality in the conflict: in many cases, participation in crowdfunding is visible and crowdfunding campaigns rely on networked amplification and diffusion on social media. From this point of view, crowdfunding becomes an open question to your network: "Are you with us, or are you against us?". From the case study above, we can see crowdfunding platforms not only reconfigure the relationship between spectators and the hyperconnected battlefield by challenging the centrality of power in military and humanitarian logistics, but also create the conditions of possibility - some might call it hope - for post-conflict reconstruction and a future after the military conflict. This finding suggests that the second set of boundary objects representations of distant human suffering - are, by far, not the only mediators between 
spectators and the hyperconnected battlefield, which adds a new research direction to our understanding of values that drive remote humanitarianism in the digital age.

\section{References}

Acker, A. \& Donovan, J. (2019). Data craft: a theory/methods package for critical internet studies. Information, Communication \& Society, 22:11, 1590-1609.

Asmolov G. (2021). From sofa to frontline: The digital mediation and domestication of warfare. Media, War \& Conflict. doi:10.1177/1750635221989568

Boichak, O. (2017). Battlefront Volunteers: Mapping and Deconstructing Civilian Resilience Networks in Ukraine. In 8th International Conference on Social Media and Society: Social Media for Good or Evil, \#SMSociety 2017 (Vol. Part F129683).

Boichak, O. (2019) Mobilizing Diasporas: Understanding Transnational Relief Efforts in the Age of Social Media. Proceedings of the 52 Annual Hawai'i International Conference on System Sciences. doi: 10.24251/HICSS.2019.336

Boulianne, S., Minaker, J., \& Haney, T. J. (2018). Does compassion go viral? Social media, caring, and the Fort McMurray wildfire. Information, Communication \& Society, 21(5), 697-711.

Chouliaraki, L. (2015). Afterword: The dialectics of mediation in 'distant suffering studies'. The International Communication Gazette, 77(7), 708-714.

Hoskins, A., \& O'Loughlin, B. (2010). War and media: the emergence of diffused war. Cambridge, UK ; Malden, MA: Polity.

Merrin, W. (2018). Digital War: A Critical Introduction. Routledge.

Star, S. L., \& Griesemer, J. R. (1989). Institutional Ecology, 'Translations' and Boundary Objects: Amateurs and Professionals in Berkeley's Museum of Vertebrate Zoology, 1907-39. Social Studies of Science, 19(3), 